\title{
Bahasa Non Verbal Dalam Komunikasi
}

\author{
Oleh: Nani N. Sarah
}

Nani20.sarah@gmail.com

\begin{abstract}
Abstrak
Sering kali kita mengeluh atau mendengar keluhan mengenai apa-apa yang disampaikan oleh seorang oembicara. Secara intuisi kita setuju dengan kata-kata yang diucapkannya, tetapi seringkali otak kita menangkap ada pesanpesan lain dibelakang kata-kata tersebut. Bahkan kita berkesimpulan bahwa maksud si pemvbicara justru kebalikan dari kaliman yang diucapkan. Hal ini dapat terjadi karena penilaian kita berdasarkan evaluasi dari nada, intonasi, tekanan kata atau ekspresi wajah, sikap, gerak tangan, jarak pembicara dan kontak mata - yang mana semua ini adalah simbol-simbol non-verbal atau disebut juga silent language (=bahasa bisu).
\end{abstract}

\section{Kata kunci: Bahasa, Non verbal Komunikasi}

\section{PENDAHULUAN}

Simbol/ tanda non-verbal cenderung dipakai untuk memperkaya dan men-support bahasa dan mampu mengurangi atau bahkan berlawanan dengan pesan verbal. Contohnya pada kalimat, "saya ingin sekali berjumpa dengan anda dan membicarakan masalah ini lebih lanjut." Kalimat ini bisa memberi pengertian yang berbeda tergantung dari bahasa Non-verbal yang mendampingi ketika kalimat ini diucapkan.

Misalnya:

1. Bila diucapkan dengan tersenyum sambil mengambil dan menunjuknunjuk kalendar Tandanya men-support makna kalimat. 
2. Bila diucapkan menyambung dengan topik berikutnya tanpa memberi tekanan pada kalimat. Berarti pembicara cenderung tidak sungguhsungguh

${ }^{2}$ Dosen Program Studi Sekretari Fakultas Ekonomi Universitas Pamulang dengan kalimatnya itu dan berarti pada saat ini setidaknya dia tidak menaruh perhatian pada anda.

1. Bila diucapkan dengan mengerutkan alis/dahi sambil berlagak mencari sesuatu

Dimejanya - tandanya berlawanan dengan makna kata yang diucapkan.

\section{PEMBAHASAN}

\section{Komunikasi Face-to-face}

Beberapa peneliti mengatakan bahwa dalam komunikasi face-toface/ berhadap-hadapan hampir 93\% diantara pesan-pesan verbal atau lisan disampaikan secara non-verbal dan elemen-elemen non-verbal umumnya lebih mengena dari pada kata-kata atau verbal.

Contohnya: anda akan maklum apa yang dimaksud oleh rekan anda ketika Ia melukiskan kecantikan seorang wanita dengan kalimat yang tidak selesai, "pokoknya...," (anda melihat gerak kepala, tubuh dan tangannya yang menggambarkan sebuah gitar). Makna dan interpretasi sesungguhnya terntu tergantung dari berbagai faktor.

Dalam tulisan ini kita akan melihat berbagai budaya mempunyai bahasa non-verbal yang berbeda makna. Satu contoh disini misalnya: di negara barat, kontak mata menunjukkan kejujuran, sedangkan di Asia menunjukkan sikap kasar atau menantang. Interpretasi bahasa non-verbal dipersulit lagi dengan kenyataan bahwa dalam aturan budaya tidak menggunakan tanda yang sama. Pria dan wanita sering menggunakan bahasa non-verbal yang berbeda. Pria barat cenderung lebih terus terang 
berbicara/ blak-blakan daripada wanitanya. Namun demikian dalam dua dekade ini, dengan adanya hak-hak persamaan wanita, cara berkomunikasi kaum wanita mengalami perubahan. Dalam banyak budaya, orang-orang dari strata sosial tertentu menggunaklan bahasa non-verba; yang berbeda. Orang dari kelas atas atau orang yang mempunyai posisi sering kali lebih asertif dan bicara terus terang dibanding dengan orang dari kelas rendahan/ kelas bawah.

\section{faktor yang Memengaruhi Bahasa Non-Verbal?}

Sebenarnya banyak faktor yang memengaruhi bahasa non-verbal, diantaranya:

- Background budayanya

○ Background sosial-ekonominya

○ Pendidikannya

○ Gender/jenis kelamin

- Umur/usia

- Pengalaman pribadi yang dialami \& keistimewaan yang dimiliki.

Kesemua faktor ini mempersulit interpretasi komunikasi nonverbal. Tidak ada aturan baku tertentu sehingga kita harus selalu melihat konteks situasi. Contohnya di negara barat, orang tangan didada bisa diartikan sebagai sikap defensive/bertahan atau menolak orang atau cupat. Bisa juga tanda ini berarti bahwa si pembicara adalah orang yang kaku atau bisa jadi tidak mempunyai arti tertentu. Simbol non-verbal lain yang juga menarik untuk disimak, tetapi tidak penting karena tidak merubah pesan ialah ketika orang Eropa menggunakan jari-jari mereka ketika menghitung angka hingga 5. Mereka akan mulai dengan jempol hingga kelingking. Orang Amerika akan mulai dengan telunjuk menuju ke jari kelingking dan jempol dihitung terakhir. 
Lalu mengapa kita musti mempersoalkan komunikasi Non-Verbal bila interpretasinya demikian sulit? Masalahnya adalah justru karena mereka amat beragam dan mengandung banyak makna. Bisa jadi deskripsi lengkapnya mempunyai banyak variasi dalam budaya itu sendiri. Dengan cara mempelajari budayanya, kita dapat memahami bahasa non-verbal yang umum digunakan. Pemahaman budaya, mempermudah interpretasi/men-decode simbol-simbol yang ada sehingga kita dapat menyampaikan pesan dengan lebih efektif.

Apa sih sebenarnya bahasa non-verbal itu? Para peneliti sepakat menyebutnya sebagai bahasa tanpa kata (bahasa isyarat). Selain itu mereka juga mendefinisikannya dalam 2 (dua) kategori:

1. Komunikasi Non-verbal semata yang menggunakan tubuh termasuk paralanguage. (Jalaludin Rahmat mengelompokkannya dengan istilah gerak tubuh paralingistic/suara).

2. Bahasa Non-verbal/ bahasa isyarat termasuk SEMUA aspek komunikasi meliputi lisan dan tulisan. Termasuk aspek dalam hubungan dan barang-

barang materinya, serta aspek Non-verbal dari bahasa tulisan seperti berat dan warna surat, format ukuran, huruf cetakan dan menjilid sesuatu. (jalaludin Rahmat menyebutnya sebagai faktor faktual/penampilan/pakaian).

Dalam tulisan berikut akan kita lihat secara lebih seksama mengenai dua (2) hal diatas.

\section{Paralanguage/paralingusitik}

Paralanguage dalam bahasa Indonesia diterjemahkan sebagai paralinguistik, yaitu yang berhubungan dengan suara atau nada ketika mengucapkan kata. Bisa juga berupa suara ketika manusia mengeluarkan 
suatu bunyi dari mulutnya yang mempunyai arti dan dianggap sebagai sarana komunikasi antar manusia.

$\rightarrow$ Mengucapkan kata dengan cara tertentu dan memberi makna tertentu.

Maksudnya 1 (satu) pesan verbal yang sama dapat memberikan arti yang berbeda bila,

Diucapkan dengan cara yang berbeda atau diucapkan dengan intonasi yang berlainan untuk

Menunjukkan pertanyaan, keraguan, keyakinan atau penolakan.

Contoh pada kalimat: AYAH SIDIN MENGAMBIL RANTAI ANJING

○ Berhentilan pada Ayah dan mengucapkan dengan nada memanggil:

Ayah $\sim$ Sidin

Mengambil rantai anjing.

○ Sekarang anda berhenti pada kata Sidin: Ayah Sidin $\sim$ mengambil rantai anjing

○ Sekarang anda berhenti pada rantai: Ayah Sidin mengambil rantai $\sim$ anjing.

Paralinguistik berada diantara komunikasi verbal dan nonverbal karena dianggap melibatkan suara saja tanpa kata-kata.

Para peneliti membagi paralinguistik kedalam 3 (tiga) kategori, yaitu:

$\checkmark$ Kualitas bunyi/suara

$\checkmark$ Nada suara

$\checkmark$ Cara menyembunyikan suara

\section{Kualitas bunyi/suara - Vocal Quality}

Kualitas bunyi atay syarat ini nampaknya lebih bersifat individual. Artinya lebih pada individi/ sifat dan karakter perorangan dan bukan sufat/karakter budaya. Sehingga 'kualitas suara' tidak akan dibahas disini. Pembahasan hanya meliputu 2 berikut yakni, Nada Suara dan Membunyikan Suara saja. 
Yang umummum diketahui bila seorang pembicara menurunkan nadanya diakhir kalimat, ini menunjukkan bahwa Ia telah selesai berbicara dan mengundang orang lain untuk merespon.

\section{Nada Suara - Vocal Qualifiers}

Berbicara mengenai Nada Suara berarti membahas volume (keras/lemahnya suara), pitch (tinggi/rendahnya suara) serta lagu atau intonasi kalimat yang diucapkan. Penggunaan Nada suara berbeda-beda antara tiap bangsa. Berikut adlaah contoh-contoh yang dapat ditemui:

- Pembicara menaikkan atau menurunkan suaranya pada akhir kalimat.

Dalam bahasa inggris pembicara menaikkan suara pada akhir kalimat tanya, maka ia menanti sebuah jawaban.

:Where do you live?

$\rightarrow$ Sedangkan bila si pembicara tidak menaikkan suaranya diakhir kalimat, maka Ia tidak menanti jawaban atau hanya ingin menyatakan ide-nya saja. Bukan mencari sebuah jawaban.

:Where do you live is not important.

- Pembicara memberi kecepatan kata yang diucapkan.

$\rightarrow$ Kaum pria di jepang berbicara lebih cepat daripada kaum wanitanya, bagi orang asing, pria jepang terdengar seperti 'berkumus-kumur' ketika berbicara.

- Pembicara berteriak keras atau bernadakah lembut.

$\rightarrow$ Orang dari suku batak cenderung berteriak bila berbicara, karena mereka tinggal dilingkungan pegunungan atau batu kapur yang letak rumah tinggalnya berjauhan satu sama lain. Letak geografis juga bisa

memengaruhi. Orang pesisir cenderung bersuara lebuh keras seperti orang gunung karena mereka harus mengatasi suara angin dan ombak laut agar terdengar. 


\section{Cara Mempunyikan Suara}

Hampir semua budaya menggunakan suara-suara yang bukan berasal dari kata seperti dehem "aham, mmh..., er..." atau desah ketika mengambil nafas atau dengan membunyikan lidah.

Semua suara ini digunakan sebagai oenghubung anatar ide-ide si pembicara. Mereka bisa juga dipakai untuk menunjukkan bahwa seseorang telah siap mengatakan sesuatu atau menunjukkan bahwa Ia memerlukan sedikit waktu lagi untuk berpikir.

Sehingga kesimpulannya, interpretasi suara-suara ini tidak menimbulkan suatu kesulitan hubungan dalam komunikasi antar budaya tetapi alangkah baiknya bila kita memahaminya. Masih mengenai vocalization/cara membunyikan suara dari "non-word", contohnya dalam bahasa inggris kata OK dan You Know seringkali sebagai fillers/pengisi antara dua kalimat.

Contoh 1: "I don't understand every single word.... You know... i just guest some of them."

Kata-kata you know ini sebenarnya mempunyai makna tertentu tetapi si pembicara menggunakaannya tidak dalam konteks makna kalimat itu sendiri. Dia memakainya hanya sebagai jembatan saja.

Contoh 2: kata/Haik (artinya "ya") dalam bahasa jepang. Mereka lebih sering digunakan tidak dalam konteks sebenarnya, sehingga dalam kalimat mereka tidak punya makna tertentu. Kata tersebut hanya berfungsi sebagai selingan saja.

Gambar 1 


\section{BAGAN PARALANGUAGE/PARALINGUISTIK}

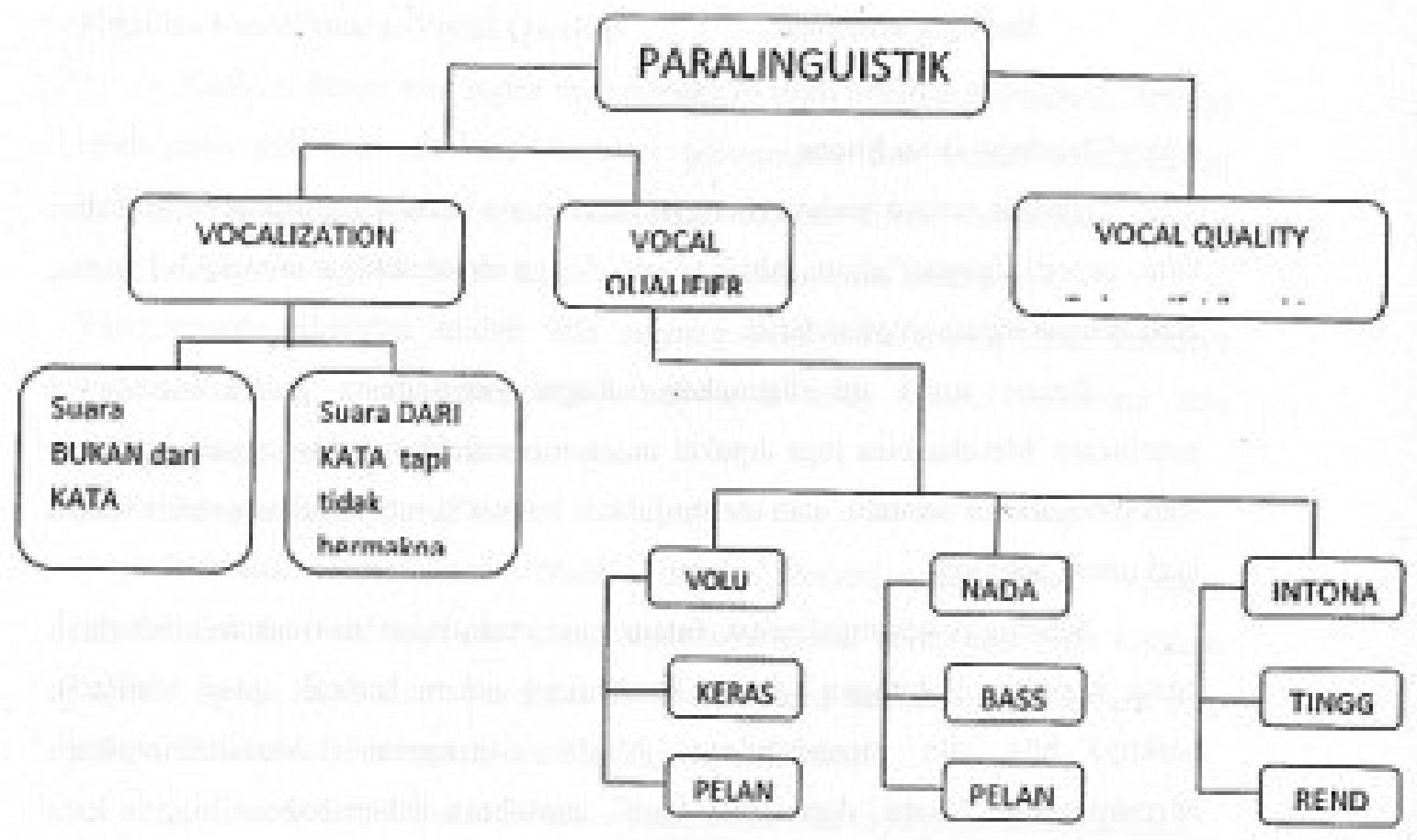

Pesan-Pesan Non-verbal dalam Komunikasi Face-To-Face

Pesan-pesan non-verbal dapat dibagi menjadi sub-kategori.

Maksudnya adalah untuk memepermudah, namun demikian jangan sekalikali beranggapan bahwa mereka menggunakan simbol-simbol non-verbal secara terpisah. Umumnya pembicara menggunakan berbagai macam simbol secara bersama-sama. Pesan Non-verbal dapat kita kelompokkan menjadi 2 (dua), yaitu:

1. Gerakan tubuh

2. Hal lain diluar gerakan tubuh (versi Jallaluddin Rahmat)

Dalam berbicara seringkali kita melihat seseorang menggerakgerakkan tangannya, mengangguk-anggukkan kepalanya, tersenyum sambil menatap mata. Pesan nonverbal yang menyulitkan pendengar adalah yang diucapkan bersamaan dengan kata-kata; yaitu nada suara, raut wajah seseorang ketika mengucapkan kata-kata tersebut atau tidak adanya kontak mata. Yang terakhir ini membuat kita bertanya-tanya: apakah lawan bicara kita mengerti apa yang kita katakan? 
Dalam tulisan ini, pembahasan dimulai dari simbol-simbol yang hampir selalu mendampingi pesan-pesan verbal lalu bergeser ke simbol-simbol yang tidak ada hubungannya dengan kata sama sekali: seperti jarak berbicara, penampilan dan diam.

Pada beberapa kasus kita bisa memanipulasi simbol-simbol tersebut. Sedemikian rupa dengan penuh kesadaran, karena orang mengharapkan hal ini dari kita. Padahal sebenarnya kita tidak ingin tersenyum sama sekali, misalnya. Umumnya kita mengirimkan pesan non-verbal tanpa menyadarinya. Para ahli sepakat bahwa simbol-simbol ini adalah refleksi perasaan kita dan respon ketika kita bereaksi. Salah satu tujuan komunikasi antar budaya adalah menginterpretasikan simbol-simbol ini.

Pesan-pesan non verbal dalam komunikasi face-to-face yang akan dibahas adalah:

- Tatapan/kontak mata

- Ekspresi wajah dan tubuh

- Pesan tubuh/gestures

- Kecepatan merepon lawan bicara

- Sentuhan

- Ruang lingkup bahasa

- Penampilan

- Diam

\section{EYE CONTACT/tatapan mata}

Dalam banyak budaya, orang yang mempunyai kedudukan tinggi lebih bebas melihat/memandang pada bawahannya. Demikian pula sejak dulu kaum lelaki bisa melihat para wanita tetapi tidak sebaliknya. Bahkan di Amerika mengerling pada lawan jenis diartikan sebagai sebuah bentuk gangguan sexual dan mempunyai konsekuensi hukum. Dalam budaya model ini tatapan mata menjadi sebuah masalah besar. Wanita Eropa sering berkomentar bahwa lelaku Amerika amatlah dingin dan tidak tahu bagaimana 'bermain mata'. Sebaliknya wanita amerika yang berpergian ke Eropa selatan seringkal;i merasa terganggu terhadap cara memandang pria Eropa kepada mereka. 
Tiap budaya ternyata mempunyai aturan yang berbeda dan perbedaan ini membuat orang merasa tidak nyaman tanpa tahu sebabnya.

Kebiasaan di Amerika adalah memandang arah mulut pembicara ketika mendengarkan, tetapi ketika menjadi pembicara mereka sebentar-sebentar memandang mata pendengarnya. Di negara Cina justru kebalikannya. Pembicara akan memandang pendengarnya tanpa putus tetapi seorang pendengan tidak membuat kontak mata atau bahkan melihat wajah pembicara.

Beberapa budaya menganggap bahwa mata adalah "jendela Jiwa", sehingga kontak mata memberi arti tertentu. Dalam budaya seperti ini kontak mata erat kaitannya dengan kejujuaran, sedanhgkan pada budaya lain bahkan kontak mata dianggap sebagai memasuki 'daerah pribadi' mereka.

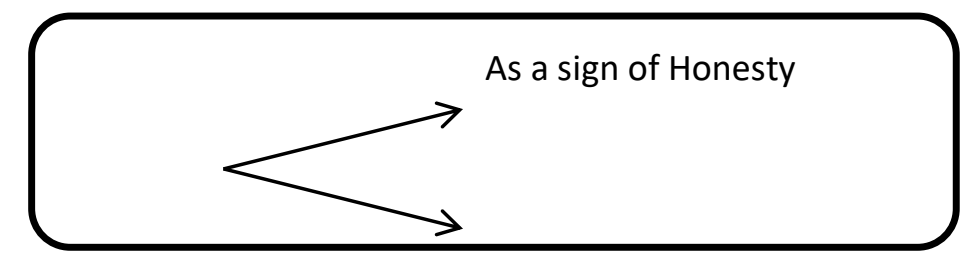

\title{
Eye Contact As a Sign of Honest/ Tatapan Mata tanda Kejujuran
}

\begin{abstract}
Ungkapan 'Dia bahkan tidak memandang mata saya,' menunjukkan bahwa di negara barat si pembicara memiliki sesuatu yang disembunyikan. Di Amerika Utara dan di eropa Utara kontak mata menunjukkan keterbukaan, dapat dipercaya serta ketulusan. Seseorang tidak perlu menyembunyikan sesuatu. Dan bila seorang wanita Amerika menatap langsung pada seseorang, berarti dia mengijinkan oranmg yetsebut memandang matanya pula dan memutuskan apakah dia seorang yang dapat dipercaya. Seseorang yang tidak melakukan kontaki mata dianggap berkelit dan hal ini membuat pendengar curiga. Orang-orang dari berbagai budaya membawa kebiasaan budayanya melalui kontak mata. Sebagaimana umumnya aspek nonverbal, kontak mata tidaklah mudah menyebrangi perbatasan negara.
\end{abstract}


Budaya arab menggunakan kontak mata lebih banyak daripada di negara Barat. Mereka amat memerhatikan gerak mata untuk menebak maksud seseorang. Menurut mereka mata tidak akan berbohong bahkan untuk melihat

mata dengan jelas, orang Arab akan mendekati lawan bicaranya, hal mana membuat bangsa non-arab merasa tidak nyaman. Seorang jepang akan merasa amat tidak nyaman dengan konta mata langsung dan kedekatan jarak antara pembicara dengan pendengar. Terlebih lagi bila mereka berdiri dengan posisi dekat, si pembicara Arab juga akan menyentuh pendengar Jepang.

Dalam hal ini orang Arab telah mengirimkan pesan non-verbal yang amat nyata dan yang mana ketiganya amat berlawanan dengan budaya orang di Jepang.

Orang-orag mengatakan bahwa pimpinan Palestina, Yasser Arafat, selalu memakai kacamata hitam sehingga lawan bicaranya tidak dapat mengikuti gerak matanya.

Diapun dapat menutupi perasaan yang sebenarnya agar tidak nampak. Sebagian orang berpendapat bahwa kacamata itu adalah upaya untuk menyembunyikan motif dan maksud hatinya. Dalam kasus lain, pembicara Arab justru mungkin ingin memperlihatkan perasaannya.

\section{Eye contact as sign of invasion of privacy/tatapan mata tanda masuk ke wilayah pribadi seseorang.}

Memandang mata seseotang di Jepang dikategorikan sebagai memasuki daerah pribadi seseorang. Hal ini dianggap amat kurang ajar. Ketika Samurai memegang kekuasaan, sebuah aturan ketat amat berperan. Siapa yang dapat melihat siapa dan untuk berapa lama seseorang dapat melihat mata lawannya. Bila aturan ini dilanggar maka Ia harus menerima resikonya. Budaya ini ternyata terbawa hingga kini. Di sebuah kantor modern di Jepang pegawai dapat duduk berdekatan, tetapu mereka jarang memandang satu dengan lainnya.

Orang Jepang merasa amat tidak nyaman bila kontak langsung pada mata dan mereka ingin selalu menghindarinya. Dengan tidak memandang langsung 
mata lawan bicaranya, berarti mereka menghargai wilayah pribadi orang tersebut. Menghargai wilayah pribadi seseorang di negara padat amatlah penting. Ketika menyambut seseorang, mereka akan saling bungkuk dan memandang jauh kebelakang lawan bicaranya. Bahkan didalam bis atau kereta yang padat, tak

seorangpun melakukan kontak mata. Sehingga cara memandang orang Amerika sudah dianggap tidak sopan.

\section{FACIAL EXPRESSIONS/ekspresi wajah}

Seringkali kata-kata yang keluar dari mulut dibarengi dengan ekspresi wajah yang berbeda. Untungnya dalam banyak budaya ketika seseorang membuka matanya lebar-lebar dan membuka mulutnya sedikit, itu pertanda bahwa Ia amat terkejut. Bila mereka suka akan sesuatu, maka mata mereka akan berkilat-kilat dan mungkin pula tersenyum. Ketika mereka marah, mereka akan mengerutkan alis serta memicingkan matanya. Perbedaannya hanya terletak pada frekuensi serta intensitas penggunaannya. Perbedaannya hanya terletak pada frekuensi serta intensitas penggunanya. Orang-orang Amerika Latin dan Arab menggunakan lebih banyak ekspresi wajah sedangkan orang-orang Asia Timur lebih banyak menahannya.

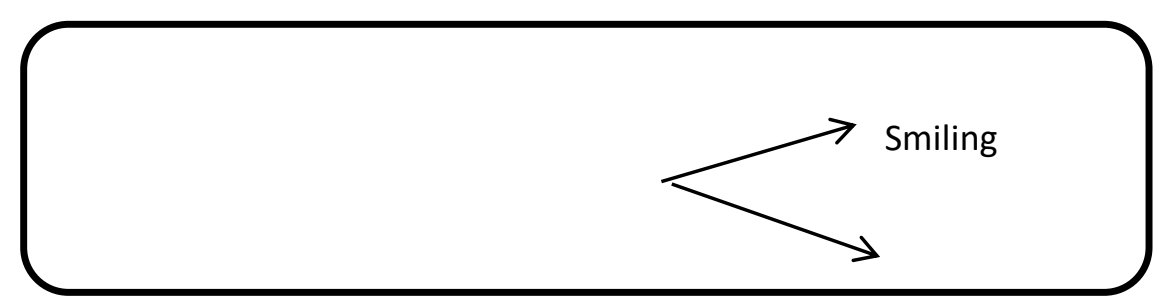

\section{Senyum/smiling}

Orang diberbagai budaya memberi senyum pada tiap kesempatan, walaupun maksudnya bervariasi. Tergantung pada budayanya, senyum bisa menunjukkan kegembiraan tetapi bisa juga menunjukkan rasa malu.

Dalam upaya agar nampak terbuka dan ramah, orang Amerika banyak menebar senyum. Mereka selalu saling senyum. Bagi budaya lain senyum Amerika ini sering tampak tidak tulus atau kaku. Misalnya: mengapa seorang 
pramusaji tersenyum? Pemilik restaurant di Amerika menghabiskan waktu cukup lama untuk melatih karyawannya sehingga mereka menampilkan senyum yang pantas. Mereka amat terkejut ketika mengetahui bahwabelahan dunia lain tidak mempunyai senyum yang sama dengan mereka. Perusahaan McDonald do Moskow punya kesulitan untuk melatih pegawai lokalnya untuk tersenyum dan memahami pentingnya arti sebuah senyman.

Orang Jepang tidak memiliki senyum sebagaimana orang Amerika. Di jepang seseorang tidak mudah memperlihatkan perasaan dan emosinya terhadap orang lain. Pria tidak tersenyum di umum; dan para wanita tidak diperkenankan memperlihatkan giginya ketika tersenyum. Untuk menjamin agar giginya tersembunyi, wanita Jepang meletakkan tangannya didiepan mulutnya ketika mereka tertawa. Para wanita yang bekerja di bank dan toko menyambut tamunya dengan membungkuk, tetapi tidak tersenyum seperti standard senyum orang Amerika. Walaupun mereka nampak menyenangkan tetap saja mereka tidak tersenyum sebagaimana orang Amerika.

Orang Jerman juga tersenyum, tetapi tidak seperti senyum orang Amerika. Mereka berpendapat 'hidup ini berat dan tak banyak yang perlu diberi senyum.' Orang Jerman tidak suka senyum dengan alasan yang berbeda dengan orang Jepang. Orang Jerman mengganggap bahwa dunia ini bukan sebuah tempat yang menyenangkan dan hidup adalah sebuah tigas yang tidak membutuhkan senyum.

Orang Korea menganggap amatlah tidak pantas untuk seorang dewasa tersenyum di tempat umum. Senyum dengan seorang asing bisa dianggap sebagai orang yang mempunyai kelainan jiwa. Korea sebagaimana halnya dengan budaya di wilayah Asia Timur, senyum bukanlah suatu ekspresi yang menunjukkan kegembiraan, tetapi lebih kepada rasa malu, ketika seorang Amerika atau Eropa merah wajahnya karena malu atau menjadi pendiam, bisa jadi orang Asia malah tersenyum. Untuk menghindari kesalahpahaman, orang yang berhubungan dengan budaya berbeda haruslah dapat mengartikan senyum-senyum tersebut dengan tepat. 
Yang berhubungan erat dengan senyum adalah tertawa. Orang Amerika bisa menghasilkan tawa yang amat lucu yang keluar dari emosi terdal;amnya. Di Arab Amerika Latin, tertawa umumnya diiringi dengan sikap tubuh seperti gerakan tangan melambai-lambai dan menyentuh. Sedangkan orang jepang jarang tertawa dengan cara itu kecuali diantara teman-teman akrabnya saja. Sebuah tawa bisa juga diartikan sebagai sebuah ekspresi ketidak nyamanan, nervous atau bahkan rasa malu.

\section{Memperlihatkan Rasa Marah/showing Anger}

Ekspresi marah juga bervariasi dari satu budaya ke budaya lainnya, baik dalam intensitasnya maupun dalam tipe ekspresinya. Orang yang lebih tua, pria dan

orang-orang yang mempunyai kekuasaan dapat menunjukkan amarahnya daripada orang muda, wanita dan para bawahan. Seorang bos bisa saja marah pada bawahannya tetapi seorang bawahan dianjurkan untuk tidak merespon dengan cara yang sama. Kesimpulannya adalah bahwa arti dan aksi marah ternyata dipengaruhi oleh budaya.

Salah satu bentuk marah yang paling awal di negara Barat adalah dengan mengerutkan dahi. Tergantung pada konteksnya, dahi berkerut dapat menunjukkan marah, keraguan, bertantanya, curiga, atau bahkan ketidaksetujuan. Dalam budaya dimana ekspresi perasaan seseorang tidak dihargai, maka mengerutkan kening menjadi terbatas. Orang Jepang contohnya, dianggap tidak sopan bila mengerutkan kening dalam memperlihatkan rasa marah dalam berbisnis.

Cara lain untuk menunjukkan rasa marah ialah dengan berteriak ditambah dengan gaya tubuh, orang Jerman, Canada, Arab dan Amerika Latin sering meninggikan suaranya ketika mereka marah. Orang Jepang jarang meninggikan suaranya, tetapi mereka menunjukkan rasa marah dengan mengambil nafas dan 
menahannya didada. Ketika orang Jerman marah, maka mereka menjadi merah dan berteriak; tetapi mereka masih sadar untuk memanggil nama lawan bicaranya dengan tepat dan benar. Mereka masih memanggil 'Sie' sebutan resmi bagi 'anda', sementara lawan bicara dari bangsa lain sudah memaki dengan sebutan macam-macam.

Beberapa budaya menggunakan gaya tubuh untuk menunjukkan rasa marah. Orang dari Timur Tengah dakan mengeluarkan kata-kata diiringi dengan gerakan tubuh yang luar biasa. Seluruh tubuh terlibat dalam menampilkan rasa marah dan ini semata-mata untuk memperlihatkan bahwa Ia benar-benar marah. Dalam hal ini menunjukkan marah bukan hanya sekadar pertempuran kata-kata tetapi juga pertempuran eksistensi seseorang.

Peneliti di kantor korea menemukan sesuatu yang menarik. Manager Korea sering memperlihatkan marahnya terhadap bawahannya, tidak hanya dengan kritik verbal namunjuga dengan aksi kekerasan non-verbal, bahkan dengan melempar kopi kearah bawahannya atau mencederai bawahannya. Pernah

pula kita menonton acara TV, bagaimana anggota parlemen Korea saling pukul dimeja perundingan. Hal seperti ini dirasa aneh, karena Asia sebenarnya terjenal dengan rasa kasih dan hamoni/keserasian.

Budaya Asia cenderung membatasi ekspresi wajah sesuai dengan standard budaya barat. Sehingga rasa marah tidaklah diperlihatkan dalam lingkungan pekerjaan. Orang Asia mampu membaca pesan dari wajah, tetapi orang Barat merasa sulit melakukannya, orang dari Timur Tengah akan sulit terbaca ketika Ia marah, tetapi kawan sebangsanya akan mudah saja melihat ini. Masalah akan timbul bilamana orang dengan budaya berbeda masuk pada suatu budaya lain yang mempunyai sistem yang berbeda ekspresi wajah dan gerak tubuhnya. 


\section{PESAN GESTURAL TUBUH/Gestures}

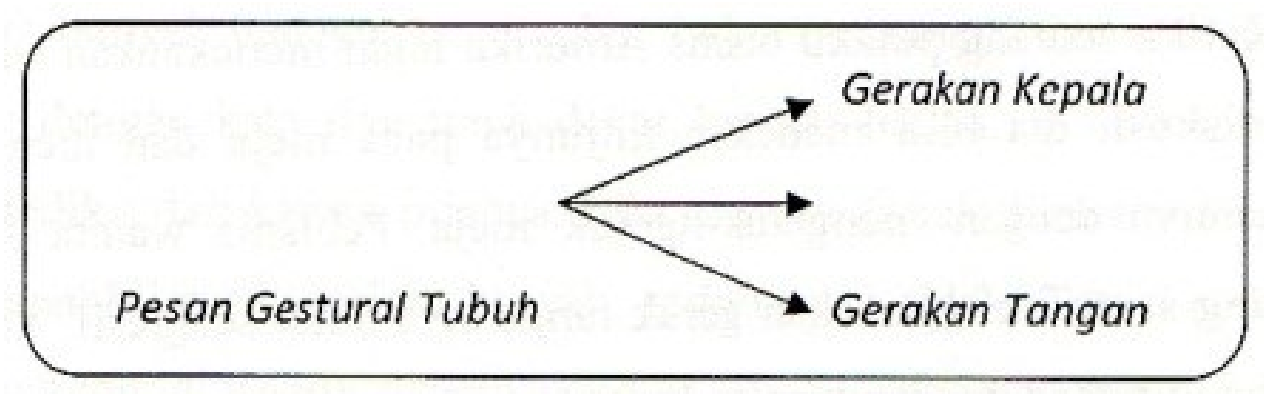

*Pesan postural: berkenaan dengan keseluruhan anggota tubuh

\section{Gerakan Kepala}

Umumnya disemua budaya, bila seseorang mengangguk, maka nampaknya Ia setuju dan bila menggelengkan kelapanya berarti menolak. Hanya sedikit pengecualian, yaitu Bulgaria. Orang Bulgaria menggelengkan kepalanya bila menyatakan setuju, serta menganggukkan kepala bila Ia tidak setuju. Begitu pula di Selatan India. Jadi ada saja disuatu daerah yang mempunyai budaya bersama terdapat satu budaya berbeda.

Seorang pembicara menganggukkan kepalanya untuk menguatkan apa yang telah Ia ucapkan. Seorang pendengar dapat menganggukkan kepalanya untuk menyatakan memahami atau menyetujui. Menganggukkan kepala dapat pula sebagai tanda bahwa pendengar mengerti dan memberi kesempatan si pembicara untuk melanjutkan percakapannya.

Menundukkan kepala pada budaya Barat bisa jadi merupakan tanda kalah atau keragu-raguan. Didalamnya budaya Asia, menundukkan kepala berarti menerima seseorang menjadi atasannya. Sedangkan dagu yang terangkat keatas pada budaya Barat dikenal dengan bersifat somong/arogan. Bahkan di Barat ada ungkapan yang khusus untuk itu, 'His nose was on the air.' 


\section{Gerakan Tangan}

Gerakan tangan mempunyai makna besar bagi manusia, sehingga ini akan menjadi ukuran seorang pembicara. Pembicara yang menggunakan gerakan tangan/lengan daoat mengintimidasi pendengarnya dan sering tampak lebih kuat. Dalam banyak budaya, pria cenderung memakai gerak tubuh lebih banyak daripada wanita.

Ketika seorang pelaku bisnis Amerika ingin menekankan suatu hal dalam sebuah diskusi, dia bisa menekan tunjunya pada meja dan menggaris bawahi pernyataannya dengan mengetuk-ngetuk meja. Pebisnis wanita Amerika pada posisi yang sama menggunakan gerak tangannya tidak seagresif kawan prianya, tetapu dibandingkan dengan wanita Jepang, maka wanita Amerika lebih agresif.

Pria Arab menggunakan gerak tangan lebih dari pada orang Amerika. Gerak tubuh dan melambai mengiringi hampir semua kata dan memerlukan ruang yang luas. Gerak tangan dapat memberi tanda bahwa semua kata dan memerlukan ruang yang luas. Gerak tangan dapat memberi tanda bahwa orang tersebut gembira tetapi bisa juga marah. Dalam proses menggerakkan tangannya orang Arab mungkin saja menyentuh pendengarnya. Bagi orang Arab nampaknya katakata kurang cukup mewakili pesan yang ingin disampaikan. Kesimpulannya: pesan non-verbal tidak hanya menemani bahasa lisan, tetapi merupakan bagian yang tidak dapat dipisahkan dari pesan-pesan verbal.

\section{Pesan Postural/Gesture}

Cara kita duduk, berdiri dan berjalan sebenarnya mengirimkan sebuah pesan nonverbal. Dibudaya Barat, beridiri tegap menandakan keyakinan, orang yang punya keyakinan akan berdiri tegak dengan bahu kebelakang dan kepala diangkat. Pesan yang disampaikan adalah: 'saya seorang yang tidak takut sesuatupun.' Pesan tubuh yang tepat berhubungan dengan status seseorang dalam masyarakat. Contohnya, seorang manager berdiri tegak ketika berbicara dengan 
bawahannya, tetapi bawahannya membungkukkan bahu ketika berbicara kepada managernya. Dalam masyarakat tradisional, orang yang tidak mempunyai posisi hirarki cenderung mengecilkan dirinya didepan kepala suku atau tetua desa untuk menunjukkan respeknya. Didalam berkomunikasi dengan budaya lain, sebaiknya seorang manager international mengetahui pesan postural yang sebagaimana diharapkan oleh lingkungan daerah tersebut.

Hampir dalam semua situasi bisnis, orang duduk dikursi; tetapi di Arab para lelaki menjalankan bisnis dengan duduk di lantai. Dalam masyarakat tradisional Jepang, bisnis dilakukan dengan duduk di lantai. Posisi kaki yang terlipat ada orang jepang membuat orang non-Jepang tersiksa selama duduk di lantai.

Dalam banyak budaya, wanita dari kelas menengah dan atas diharapkan untuk duduk dengan kaki dan tumit dekat kepada badan. Wanita memerlukan ruang lebihg sedikit dari kawan prianya. Bila mereka duduk dikursi malas, mereka nampak mengambil ruang terlalu banyak, sedangkan pria tidak. Tetapi pada 2 (dua) dekade belakangan ini wanita Amerika duduk sebebas rekan prianya.

Cara kita menggunakan badan kita ketika berkomunikasi menunjukkan bagaimana kita dapat memperlihatkan kekuatan kita, kekuasaan dan posisi kita terhadap lawan bicara. Bila kawan bicara berasal dari budaya yang sama maka dia bisa membaca pesan dengan baik, tetapi jika kawan bicara berasal dari budaya yang tidak sama, maka dia mungkin mendapat kesulitan.

Dia bisa saja mengartikan kurangnya gerak tubuh sebagai sebuah penolakan atau bahkan bila berlebihan ketika menggerak-gerakkan tubuh malah membuat ketakutan.

\section{Timing in Spoken Exchanges/ketepatan merespon lawan bicara}

Sebuah percakapan adalah pertukaran bahasa verbal/oral antar manusia. Sementara pengucapan kata-kata yang jelas amat penting, ketepatan waktu ternyata juga membawa pesan-pesan non-verbal yang signifikan/penting. Untuk 
mempelajari timing pada komunikasi nonverbal, kita sebaiknya menjawab dulu beberapa pertanyaan berikut:

1. Siapakah yang berinisiatif memulai percakapan?

2. Bagaimana pola frekuensi merespon?

3. Sikap yang bagaimana kiranya diterima untuk menginterupsi pembicara?

4. Bagaimana kiranya pola untuk mengakhiri percakapan?

Dalam budayanya sendiri, orang mengetahui pola kalimat tertentu dalam sebuah percakapan. Untuk kaum pendatang, persoalan ketepatan merespon ini rupanya menjadi masalah karena ternyata berhubungan dengan isu gender, status, dan hirarki, dalam banyak budaya para lelaki berinisiatif lebih banyak dari para perempuan; orang tua sering memulai lebih dulu pembicaraan dari orang yang lebih muda. Dan orang yang mempunyai kedudukan lebih banyak memulai percakapan dari orang bawahannya dan sikap ini terbawa kedalam kantor.

Pertanyaan 2 dan 3 saling berhubungan. Siapapun yang menginterupsi biasanya mengontrol percakapan. Pola ini umumnya sama bagi semua budaya. Kecuali di Jepang, menginterupsi percakapan, tidak dapat diterima.

Dalam budaya dimana menginterupsi pembicaraan diterima, para pebisnis pria cenderung lebih sering menginterupsi pebisnis wanita. Orang yang lebih tua lebih sering menginterupsi orang muda dan orang yang mempunyai jabatan akan menginterupsi lebih sering bawahannya. Sebenarnya tiap orang dapat mengakhiri percakapan, tetapi lebih sering orang-orang yang mendominasi tadilah yang mengintrol akhir percakapan. Peran fender, usia dan kekuasaan dalam mengatur percakapan dalam hampir semua budaya mungkin menunjukkan bahwa perbedaan budaya tidak menjadi masalah, walaupun terdapat sedikit perbedaan.

Contoh: walaupun penelitian menunjukkan bahwa pria Amerika mendominasi percakapan, tetapi wanita Amerika lebih asertif dan lebih terbuka dalam bisnis dan di umum daripada wanita Arab atau wanita Jepang. 
Contoh-contoh berikut ini menggambarkan sikap yang tepat di 3 (tiga) lingkungan berbeda:

1. Lingkungan yang menekankan kesetaraan

2. Lingkungan yang menekankan senioritas dan hirarki

3. Lingkungan yang menekankan pada pria

Area ini kadang overlap/saling tumpang tindih, contohnya di jepang, mereka menghargai senioritas, tetapi hidup juga mendominasi kaum pria. Di saudi para wanita tidak berkeliaran di umum, tetapi senioritas memegang peranan dalam kehidupan baik pria maupun wanita-nya.

\section{Lingkungan yang Menekankan Kesetaraan}

Hampir semua orang Amerika mempunyai aturan berganti-gantian berbicara ketika berdiskusi. Pembicara akan memberikan tanda-tanda bila Ia mengundang orang lain untuk berbicara atau untuk menunggu, bahkan untuk berdiam diri. Pendengarpun umumnya mengirimkan pesan apabila Ia ingin turut dalam percakapan itu.

Tanda-tanda ini tertanam dalam diri seseorang dan kebanyakan orang tidak menganggapnya sebuah hal yang serius hingga tiba pada kenyataan yang berbeda dengan harapan. Salah satu tanda bagi orang Amerika ketika menunggu sebuah jawaban adalah dengan merendahkan suaranya, menunggu diujung kalimat, gerak tubuh yang emnanti respon atau melihat wajah lawan bicara dan mengharap jawaban.

Para wanita dan orang muda Amerika menjadi lebih asertif belakangan ini dan emngiasai pembicaraan dengan baik. Banyak perusahaan melakukan kebijakan 'buka pintu' terhadap kreatifitas karyawannya. Mereka mendorong bawahannya untuk melakukan komunikasi dengan penasihat mereka dan mengkomunikasikan ide-idenya secara lebih terbuka. Akhirnya karyawan dapat menguasai sekaligus ketepatan komunikasi verbal dan nonverbal. 


\section{Lingkungan yang Menekankan Senioritas dan Hirarki}

Kontrol percakapan dalam budaya Jepang di dominasi senior, yang mempunyai posisi hirarki yang cukup tinggi. Orang uang lebih muda harus menunggu bila ingin menjawab dan harus selalu menghindar tatapan mata ketika berbicara. Untuk seorang non Jepang dilingkungan Jepang hal ini menimbulkan kesulitas karena kebanyakan percakapan dilakukan secara nonverbal dan tandatanda nonverbal sulit terbaca oleh mereka.

\section{Lingkungan yang Menekankan Kaum Pria}

Berlawanan dengan Jepang, orang Arab amat banyak bicara. Orang Arab amat menikmati tukar pikiran. Pada pandangan pertama, seseorang mungkin akandapat gambaran bahwa tiap orang akan menginterupsi yang lainnya dan 'terjun' langsung dalam percakapan.

Tetapi kemudian tampak orang yang lebih tua mengontrol percakapan tersebut. Para wanita Arab tidak berbicara di depan umum dan mereka jarang terlibat pada usaha/bisnis. Percakapan umumnya dilakukan oleh pria dan wanita berperan proaktif.

\section{TOUCHING/sentuhan}

Dalam banyak pertemuan bisnis, jabat tangan menjadi sentuhan yang diterima para pebisnis ketika pertama kali bertemu, menggantikan ritual tradisional. Tetapi model berjabat tangan amat bervariasi (lihat tabel 6-1) orang Jerman dan Amerika cenderung melakukan jabat tangan yang menggenggam sebagai simbol dari kekuatan dan karakter. Orang perancis umumnya mempunyai jabat tangan yang lebih lembut. Mereka merasa tidak nyaman dengan genggaman orang Jerman dan mungkin orang Jerman akan heran dengan jabat tangan Perancis yang dirasa patah seperti tak bertenaga. 
$\underline{\text { Tabel .- Jabat Tangan }}$

\begin{tabular}{|l|l|}
\hline Negara & Model Jabat Tangan \\
Perancis & Berjabat tangan erat \\
Jerman & $\begin{array}{l}\text { Berjabat tangan lembut } \\
\text { Berjabat tangan erat, untuk laki-laki diiringi dengan } \\
\text { sedikit membungkuk }\end{array}$ \\
Tepang & $\begin{array}{l}\text { Berjabat tangan dengan memberi jarak tegas, diiringi } \\
\text { dengan membungkuk }\end{array}$ \\
Tengah & $\begin{array}{l}\text { Berjabat tangan dengan meletakkan tangan yang lain } \\
\text { diatas jabatan tangan }\end{array}$ \\
\hline
\end{tabular}

Berjabat tangan dengan membungkuk menunjukkan ritual/adab ketika menyambut seseorang. Bungkuknya orang Jerman berbeda dengan bungkuknya orang Jepang.

\section{Gambar 2}

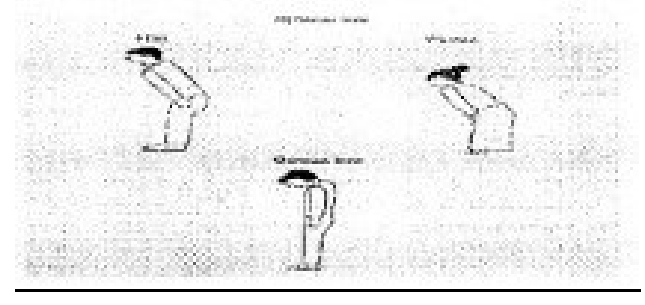

Bungkuk Jerman disebut Diener. Artinya adalah bungkuk untuk mengenali, menunjukkan otoritas/kekuasaan. Kata Diene sendiri berarti pelayan, jadi dengan membungkuk orang Jerman mengatakan:" At your service"/ siap melayani anda. Orang-orang tua Jerman mungkin masih melakukan Diener, tetapi kebanyaka orang sekaramng hanya memberi anggukan kepala saja. 
Membungkukkan kepala tidak cocok dengan jiwa demokrasi dan kesetaraan. Kanselir Helmut Kohl ketika menjabat dikritik oleh banyak orang dan majalah karena melakukan Diener ketika menyambut presiden Bush. Sikap tubuh ini dilihat oleh rakyat Jerman sebagai sikap yang tidak dapat diterima.

Di Argentina, ketika para wanita berjumpa dengan teman sekerjanya atau kawannya, mereka saling bersentuham pipi kanannya/cium pipi. Para wanita melakukannya kepada wanita ataupun pria. Sedangkan pria hanya melakukannya terhadap wanita saja. Dengan tidak melakukan ini, maka dianggapnya perjumpaan itu berkesan dingin, tidak bersahabat dan mungkin marah.

Di Lebanon, khususnya pria akan melakukan cium pipi kanan dan kiri, kemudian pipi kanan sekali lagi terhadap pria lain. Di Estonia mereka berjabat tangan pada perjumpaan dan diulang ketika berpisah.

Dalam budaya jerman berjabat tangan paling banyak dipakai dari seluruh budaya lain. Kenyataannya bentuk sentuhan ini diterima dan diharapkan dalam hampir semua situasi, baik dalam menyambut orang baru atau kerabat. Dengan tidak mebgikuti kebiasaan ini kita dianggap tidak santun. Di Jerman, berjabat tangan adalah ritual penyambutan yang diberikan dan selalu diharapkan; walapun demikian orang Jerman jarang berpelukan. Bahkan berangkulan diantara anggota keluarga, tidak dilakukan seperti di Perancis atau di negara lain.

Jabat tangan adalah sentuhan pada tangan, sedangkan berangkulan dianggap terlalu banyak sentuhan pribadi.

Suku Maori di New Zealand mengharapkan sentuhan sebagai bagian dari ritail penyambutan. Pebisnis dari susku Maori merasa tidak disertakan dalam rapat bila penyambutan tradisional mereka, Hongi/saling tekan hidung dan karanga/teriakan wajib- tidak disertakan jetika menyambut seseorang. Mereka berfungsi sama seperti jabat tangan dalam budaya jerman. Tidak pernah terbayangkan oleh seorang suku Maori untuk tidak melakukan Hongi dan Karangan walaupun orang yang hadir adalah non-Maori. 
Orang dari budaya low-context cenderung merasa rikuh dengan orangorang budaya high-context dan orang dari high-context merasa tersisih dan ditolak oleh orang dari budaya low-context. Orang-orang sellau diharapkan mempunyai satu sikap yang sesuai dengan tingkah lakunya dan ketika tidak sesuai dengan harapan, mereka merasa bingung, ditolak atau tersisih. Setiap orang membawa segudang budaya uniknya. Sehingga ketika orang belahar lebih banyaj mengenai budaya lain, mereka berusaha menyesuaikan dengan harapannya. Mereka menjadi lebih pintar dan menyesuaikan sikapnya dengan keadaan serta menjadi lebih waspada terhadap keadaan.

Seorang Bolivia dan seorang Belanda yang bertemu dengan pertama kalinya dalam isnis akan merasa kecewa hingga keduanya mengerti bagaimana seharusnya bersentuhan. Orang Bolivia datang dari budaya yang akrab, dimana orang-orang menyentuh satu sama lain ketika berbicara. Bayangkan bagaimana dia akan mendekati rekan belandanya sesuai dengan latar belakang budayanya. Sementara orang belanda tersebut datang dari budaya yang sama sekali lain. Orang-orang mempunyai jarak satu sama lain dan bersikap dingin. Diapun akan membawa kebiasaan budayanya dalam suatu rapat. Bila mereka ingin bekerja sama, maka mereka perlu mengatasi perbedaan ini.

Bagaimana kita tahu, apa yang dimaksud dengan JARAK yang TEPAT dan sentuhan yang diterima? Ketika kecil kita belajar dengan meniru/mencontoh seseorang. Buku-buku dapat menolong, tetapi daftar dari hal-hal HARUS dan DILARANG DILAKUKAN, tidak memberi alasan yang tepat bagi perbedaan yang bersifat individu, variasi-variasi perubahan budaya sudah dikatakan berubah ketika orang beradaptasi dengan lingkungan budaya. Seringkali mereka dirubah dengan sengaja agar cocok.

Ketika Tottorio Sanchez pergi berbisnis di Chicago, dia menahan diri untuk tidak menyentuh rekan bisnisnya karena dia tahu bahwa pebisnis dari Amerika jarang menyentuh satu sama lain. Dalam kasus lain adaptasi muncul lebih sering pada tingkat intuitif dimana orang-orang tidak begitu sadar atas perubahan budaya sentuhnya. Urs Luder, seorang pebisnis dari Switzerland 
memerhatikan bahwa kunjungan terakhirnya ke Abudabi jauh lebih menyenangkan. Dia tidak setegang dan se-nervous seperti dulu dan suasananya pun lebih santai. Tuan rumahoun nampak lebih menyenangkan. Yang tidak disadari Urs adalah kewaspadaan budaya non-verbalnya telah berubah. Dia tidak menghindar ketika disentuh lawan bicaranya dan dia sendiri mendekati orangorang dengan lebih terbuka dan merasa nyaman untuk meletakkan tangannya pada tangan orang lain.

Jika kita memahami bahwa sentuhan adalah hal yang alami bagi beberapa budaya, maka kita tidak akan melawan bila seseorang menyentuh kita. Begitu juga sebaliknya, jika orang lain tahu bahwa kita membutuhkan sedikit jarak, dia akan mengatur jarak sehingga mereka merasa nyaman. Orang laki-laki di Afrika berpegangan tangan dengan pria lain ketika berjalan di jalan, pria di Timur Tengah mencium pipi pria lain ketika berjumpa. Laki-laki Rusia berangkulan dan berpelukan. Sehingga berhubungan/bisnis dengan orang dari budaya lain dapat berarti mengesampingkan budaya utuh yang dimiliki budayanya sendiri. Pada sebuah interview di TV, Presiden Anwar Sadat, emenpuk lutut PM Margaret Thatcher ditengah sebuag diskusi yang seru. Padahal kita tahu bagaimana sikap 'jaga jarak' dari seorang Inggris. Tetapi ternyata dia tidak tersinggung. Dia mengartikannya dengan bahasa tubuh yang tepat seperti layaknya dalam budaya Mesir. Kesimpulannya: kita wajib melihat suatu hal secara perspektif dan tidak tersinggung jika berteman dengan seseorang yang mempunyai budaya yang berbeda. 


\section{THE LANGUAGE OF SPACE/jarak berbicara}

Jarak bicara ternyata mempunyai kekuatan. Seberapa dekat kita bisa berdiri dengan seseorang? Kebanyakan dari kita tidak pernah memikirkan soal jarak ini. Secara intuisi kita mengetahui jarak yang seharusnya. Penggunaan jarak dalam komunikasi adalah sebuah ilustrasi/gambaran yang bagus untuk menunjukkan bahwa budaya itu dipelajari dan tidak dibawa sejak lahir. Walaupun mungkin saja orang tua kita memberikan kita beberapa instruksi lisan dengan jarak tertentu, tetapi kita belajar bersikap dan meniru. Dengan mudahnya kita mengerjakan apa yang seharusnya dilakukan, begitu pula terhadap orang Arab, Jepang, Mexico, Rusia dan semua anggota budaya lainnya. Ukuran jarak berbicara yang dapat diterima, amatlah bervariasi antar budaya-budaya tersebut. Baik untuk kita bisa jadi berlawanan bagi orang lain. Jarak sering menjadi oemisah bagi kita dan kita merasa tidak nyaman berada dengan orang yang tidak sama budayanya dengan kita.

\section{Jarak Pribadi}

Daerah pribadi kita bersifat khusus dan kita merasa terancam bila seseorang memasuki lingkaran pribadi kita. Di Amerika lingkaran ity sejauh lengan kita memanjang. Kadangkala kita menjaga jarak terhadao seseorang. Artinya kita tidak ingin Ia memasuki kehidupan pribadi kita lebih dalam. Jarak tersebyt mengecil di Perancis, negara-negara Arab dan Amerika Latin, tetapi melebar di Belanda dan Jerman. Di Jepang bahkan lebih jauh lagi. Ukuran jarak pribadi ini dipengaruhi juga oleh status sosial, gender, usia dan tingkat kekuasaan. Sikap kita terhadap jarak adalah refleksi sikap kita terhadap kerahasiaan pribadi. Jika kita mengerti bagaimana orang mengatur jarak pribadi di rumahnya, maka kita bisa melihat bagaimana mereka melakukan komunikasi ditempat kerja.

Orang Eropa utara amat menghargai privacy dan mereka mengaturnya sedemikian rupa agar tetap nyaman. Batas pagar dan pemilikan diberi garis tegas dan tiap orang yakin betul bahwa haknya tidak akan diganggu orang. Sebuah rumah Jerman dapat dipastikan memiliki pagar sekeliling dengan pintu pagar yang terkunci rapat. Setelah beberapa tahun ini, pintu pagar depan dibiarkan terbuka 
dan tidak dikunci. Apalagi makin banyak orang Jerman yang memiliki mobil saat ini. Adanya pagar merepotkan mereka memasukkan dan mengeluarkan mobil.

Di Jerman ada peraturan yang detil mengenai penggunaan halaman. Pagar harus berada dalam wilayah tanah kita. Tingginya pun terbatas. Rumah-rumah di Jerman pun amat menekankan privacy. Semua ruangan mempunyai pintu lengkap dengan kuncinya dan pintu selalu dalam keadaan terkunci. Di negara yang padar dan dimana matahari bersinar, pagar harus serendah mungkin agar matahari bisa menyinari rumput tetangga. Sebaliknya, rumah di Amerika mempunyai pagar mengelilingi halaman rumah, tetapi pintu pagar terbuka dan berkesan mengundang. Bila Ia ingin sendiri, maka pintunya akan ditutup. Privacy di Jepang berbeda dengan privacy di Amerika dan Jerman. Jepang adalah negeri yang padat, oleh karena itu ruangan adalah kemewahan. Rumah dan apartemen amat mahal. Dinding dan pintu tradisional amatlah tipis. Mereka terbuat dari kayu dan kertas sehingga suara akan mudah terdengar. Dalam keadaan padat ini, bangsa Jepang merupakan penciptaan pikiran dan bukan masalah kehadiran. Orang Amerika menghubungkan privacy dengan kondisi fisik, sedangkan orang Jepang menghubungkan privacy dengan kondisi mental.

Bangsa Timur Tengah serta Amerika Latin juga menampilkan sikap jarak pribadi ini dari cara mereka menata rumah. Rumah di Timur Tengah asalnya punya sedikit bahkan tanpa pintu ke jalan. Semua jendela terbuka kearah bagian dalam halaamn, keluarga dilindungi dari dunia luar dengan cara membentengi dirinya sendiri. Ini sudah merupakan bentuk menjaga privacy. Tetapi dalam rumah, ruang pribadi untuk perorangan amat dibatasi. Kebersamaan keluarga amat ditekankan. Untuk memisahkan diri dan mengambil tempat sendiri menjadi tidak mungkin dan tidak dapat diterima.

Kebersamaan individu adalah yang utama dalam keluarga dan penataan ruang memperlihatkan konsep itu. Dalam ruang keluarga islam, daerah pria dan wanita dipisah. Laki-laki dan wanita tinggal bersama dalam rumah, tetapi mereka tinggal dalam ruang yang terpisah.

Tabel 2: Language of Space di Beberapa Negara 


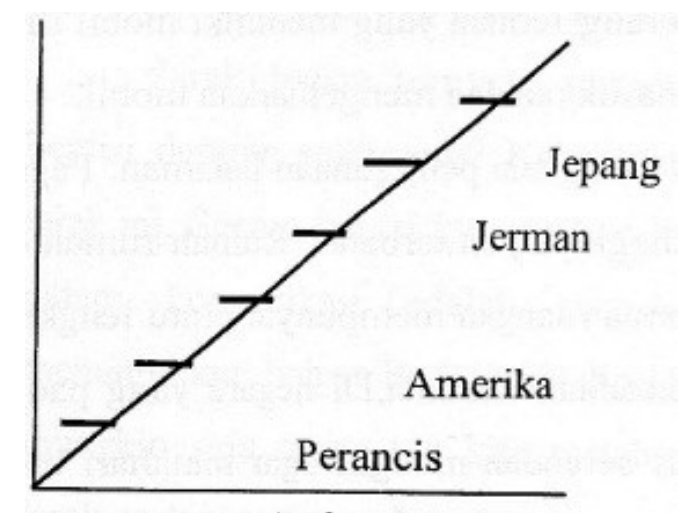

Arab

\section{Amerika latin}

\section{Jarak di Kantor}

Sikap kita pada 'Jarak Pribadi' terbawa ke tempat kerja. Umumnya budaya yang menghargai nilai ruang pribadi mempunyai ruang kantor yang luas dan mempunyai ruang kantor sendiri. Dalam budaya dimana jarak pribadi kecil, maka ukuran kantor menjadi tidak penting. Orang Jepang tidak cocok dengan pola ini.

Orang Jepang cenderung mempunyai jarak antar pribadi yang benar-benar besar, walau mereka tidak mempunyai ruang kantor pribadi. Yang musti kita ingat pada orang Jepang, pengertian 'pribadi' berarti lebih kearah fikiran dan bukan secara fisik. Lebih jauh lagi pada bangsa Jepang orientasi kelompok amatlah kuat. Seluruh ruang kantor bangsa Jepang dipengaruhi oleh nilai budaya serta pertimbangan lainnya.

Perorangan diharapkan bisa masuk kedalam kelompok dan menjunjung tujuan kelompok dan norma kelompok. Prinsipnya adalah keharmonisan. Itu sebabnya ruang kantor pribadi jarang ditemui dan disiapkan hanya untuk top manager. Tergantung pada jenis perusahaannya, manager bisa saja duduk atau bekerja di area yang sa,a dengan karyawannya. Kantor Jepang mempunyai ciri bekerja di area yang sama dengan karyawannya. Kantor Jepang mempunyai ciri meletakkan file cabinets sepanjang dinding luar kantor. Karyawan duduk dalam kelompok pada sebuah meja besar ditengah ruang (lihat gambar 6-4). Seringkali meja ini adalah meja biasa tanpa laci dan semua pekerjaan tergeletak di meja. Para karyawan duduk berhadap-hadapan satu denga lainnya, dengan pimpinan 
kelompok pada kepala meja, tak ada seorangpun yang memiliki telepon dimejanya kecuali tuntutan pekerjaan, seperti operator.

\section{Gambar 3: Tata letak kantor Jepang}

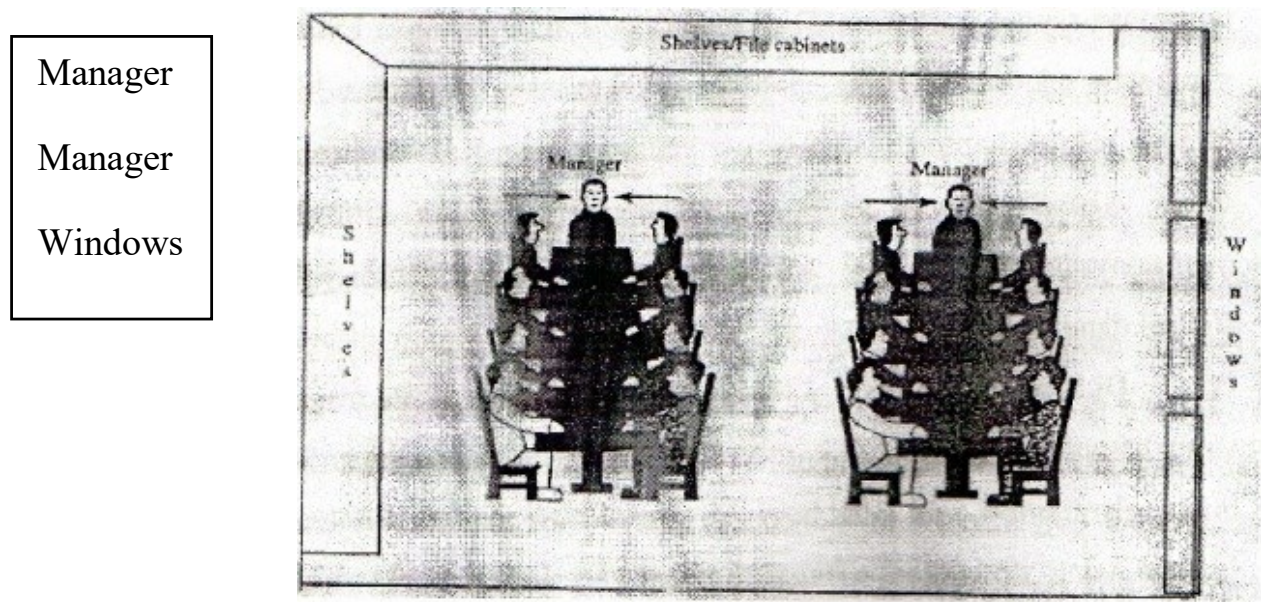

Orang Jepang yakin bahwa pengaturan ini menekankan pada pentingnya sebuah kelompok dan perlunya untuk bekerja-sama. Ketika seorang karyawan perlu mendiskusikan sesuatu dengan seorang dimejanya atau dengan seseorang dimeja lain, maka mereka akan menuju sebuah meja kecil yang berada di dekat filling cabinet agar tidak mengganggu yang lain.

Bagi orang Barat yang menekankan pada perseorangan dan privacy, maka pengaturan kantor seperti ini tidak menyenangkan; karena setiap orang saling memperlihatkan dan bahkan tidak dapat memakai telepon tanpa diketahui oleh karyawan lain. Tentu saja tidak mungkin bagi mereka untuk menelpon keluarga dirumah atau kawan diluar kantor. Orang Barat menganggapnya sebagai tidak adanya kepercayaan sama sekali.

Pengaturan duduk ala Jepang lainnya adalah dengan menempatkan meja sendiri-sendiri dengan menghadap satu arah, sedangkan pimpinannya berada didepan seperti posisi guru dalam kelas atau bahkan dibelakang sekali seperti posisi mengawasi. 
Karyawan Jepang sudah terbiasa dengan posisi seperti ini dan tidak mengalami masalah. Dalam perusahaan, karyawan adalah asset utama dan merupakan anggota grup. Mereka bukanlah per-orangan yang mempunyai hak pribadi dan daerah pribadi. Model kantor Jepang jelas-jelas mengirimkan pesan 'kami disini bersama.' Kesejahteraan bersama lebih penting dari memikirkan perseorangan. Akibatnya perabot kantor orang Jepang tidaklah penting dan umumnya sangat sederhana. Di Amerika ukuran kantor dan lokasinya merupakan gambaran suksesnya bisnis seseorang, kekuasaan dan status hirarki, di negara dimana banyak kantor tidak mempunyai jendela, maka jendela merupakan simbol status. Seorang top manager akan mempunyai ruang ditingkat atas dengan mempunyai banyak jendela. Selain itu perabot furnitur kantor juga dapat menjadi simbol dan menunjukkan status seseorang.

Di perancis lain lagi. Mereka amat terganggu dengan ruang tanpa jendela yang banyak dimiliki oleh kantor Amerika. Mereka tidak suka kepada cahaya buatan dari lampu dan tidak bisa membayangkan untuk bekerja pada ruang tanpa jendela yang dirasakan sebagai penjara. Kantor perancis merefleksikan nilai budaya sentralisasi.

Seperti halnya jalan-jalan utama di Perancis semua mengarah ke Paris, begitu juga kantor-kantor pusat selalu berada di Paris. Para top manager mengontrol semua aktifitas di kantor pusat. Kantor-kantor berada di sekeliling pimpinan dan Paris mengontrol semua kegiatan kantor di seluruh Perancis. Pebisnis meyakini bahwa seseorang tidak sukses sebelum berkantor di Paris. Pegawai yang berada di Paris akan merasa karirnya hancur hanya karena dipindah kerja ke daerah pinggiran atau ke provinsi.

Kantor orang Arab lebih merupakan sebuah temoat untuk saling berjumpa. Pelaku bisnis Arab dapat melakukan beberapa urusan sekaligus dengan orang yang berbeda pada satu hari di kantornya. Sedangkan orang Barat tidak akan merasa nyaman melakukan janji bisnis dengan cara ini. Pentingnya suatu kantor bagi orang Arab tidak ditandai dengan ruangan yang besar dan mewah, tapi lebih kepada kepadatan/ intensitas komunikasi. 


\section{Jarak di Umum}

Cara orang mengatur dan menggunakan ruang/tempat umum menggambarkan perilaku budayanya. Pelaku bisnis Amerika yang bepergian ke Jepang atau Cina sering berkomentar mengenai padatnya kota dan mengeluh tidak cukup tempat untuk bernafas lega. Mungkin benar menurut standard Amerika,

tetapi tidak bagi Jepang dan Cina. Cara mandang ruang yang sama bagi dua orang dari budaya yang berbeda bisa amat berlainan.

Contoh: Aki Hayashi, seorang professor tamu di Universitas Illinois akan bepergian ke sebuah konvensi di New Orleans. Kawan-kawan Amerikanya pergi menggunakan pesawat terbang, sedangkan Ia emmilih naik kereta api. Brien Ober, seorang kawan Amerikanya memperingatkan bahwa kereta api sangatlah padat. Tetapi Tuan Hayashi tetap pergi dengan kereta dan Brien Ober amat tercengan ketika tuan Hayashi menceritakan pengalamannya yang menyenangkan di kereta api yang menurutnya cukup leluasa.

Orang Amerika membawa ide individualnya pada tempat-tempat umumnya, mereka merasa berhak untuk berjalan-jalan di taman dan bermain di rumput taman. Mereka merasa itu adalah taman mereka, lagi pula mereka membayar pajak untuk taman tersebut. Bangunan pemerintah terbuka untuk umum. Setiap orang bisa pergi ke Capitol di Washington atau di capitol-capitol lainnya. Tidak ada warga di dunia yang bisa mendatangi rumah tinggal presidennya dengan leluasa kecuali Amerika. Tempat tinggal PM inggris dan Istana Elysee di Perancis pun tertutup untuk umum.

Orang Jerman mengatur tempat umumnya seperti mengatur hidup pribadinya. Semua harus terletak pada tempatnya. Aturan dibuat dan aturan lebih rinci dibuat untuk mengawasi agar aturan dilaksanakan. Orang Jerman terbiasa dengan perintah dan aturan. Taman-taman di Jerman tampak bersih dan rapi. Rumput tidak diinjak. Ada pengumuman untuk tidak menginjak rumput. Orang Jerman terbiasa dengan kalimat perintah "Dilarang ini... atau itu..." 
Walaupun demikian 10 tahun belakangan ini, keadaan di Jerman mulai berubah. Perubahan sikap ini menunjukkan bahwa bahasa nonverbal atas ruang dapat berubah karena waktu. Karenanya belajar komunikasi nonverbal merupakan kegiatan yang harus berlangsung terus menerus.

Orang Jerman amat agresif di tempat umum/keramaian. Orang Inggris senang mengantre untuk bus,di toko atau di bioskop. Penonton di Inggris akan otomatis megantre karcis dan mereka mengharapkan tiap orang akan mengikuti aturan tidak tertulis itu. Orang Jerman terkihat berbeda; mereka senang menyikut

dan mendesak untuk mengambil tiket. Mereka tidak sabar untuk berdiri dalam antrean. Di Amerika anak-anak kecil diajarkan untuk menunggu gilirannya dengan sabar, dan bila Ia ingin naik komedi putar untuk kedua kalinya, maka Ia harus mengulang berdiri dalam antrean berikut. Ia tidak dapat naik komedi putar itu sekaligus dua kali.

Kondisi di kota besar yang mempunyai penduduk beragam budaya akan menghadapi tantangan yang besar. Etiket tradisional dan aturan tak tertulis terancam oleh datangnya berbagai budaya. Bahasa nonverbal sedikit demi sedikit mengalami pergeseran. Contoh yang nyata dapat kita lihat pada bus dikota besar. Penumpang pria tidak lagi memberi tempat duduk pada kaum wanita. Para wanita Mexico yang bila berpergian selalu harus ditemani oleh keluarga/kerabat pria, sekarang harus bepergian seorang diri. Para pria bingung bagaimana harus bersikap terhadap wanita, karena banyak wanita agresif dan seolah-olah tidak perlu perlindungan mereka lagi.

Kondisi yang demikian ini memaksa hal-hal diluar kebiasaan nonverbal. Karena lingkungan dari suatu budaya berubah, maka masyarakat harus menetapkan standard komunikasi nonverbalnya dan mencari pengaman untuk melindungi standard tersebut.

Mau tidak mau perilaku di tempat umum akan terbawa ke dalam kantor dan urusan bisnis, karena kita tidak bisa memisahkan kebiasaan suatu budaya dari budaya bisnis. Keduanya berjalan beriringan. Bagaimana kita mendekati seseorang dan bagaimana kita berbagi ruang dan privacy mempunyai ikatan akar 
budaya. Kita bisa saja tidak suka dengan yang dilakukan orang lain, tetapi itu tidak penting. Masalahnya adalah kita harus memahami apa yang dilakukan orang lain dan mengapa mereka melakukannya.

\section{Penampilan}

Cara kita berpakaian juga ternyata berkomunikasi. Berpakaian sesuai kebiasaan dan harapan menunjukkan respek dalam hubungan selanjutnya. Tandatanda khusus yang tersirat dalam berpakaian dapat menunjukkan asal daerah anda. Ketika kita meneliti 'penampilan' maka harus dapat menjawab beberapa pertanyaan berikut:

1. Baju jenis apa yang pantas bagi pria dan wanita pada suatu budaya?

2. Apa perbedaan berpakaian ketika berbisnis dengan suatu budaya dan berbisnis dengan budaya lain lagi?

3. Seberapa penting hal yang melekat pada baju?

4. Sanksi apa yang diterima bila berpakaian yang tidak pantas?

Umumnya pakaian bisnis berupa setelan jas dengan kemeja dan dasi untuk para pria berlaku universal disemua negara, walaupun ada sedikit perbedaan pada modelnya, setelah jas pria Eropa lebih trendy dan bergaya muda daripada pria Amerika. Di Jepang bahkan lebih konservatif, mereka tetap suka dengan warna abu-abu atau biru tua. Pria Arab memakai pakaian barat ketika melakukan bisnis di Barat. Tetapi mereka akan memakai pakaian tradisionalnya berupa pakaian panjang putih dengan penutup kepala merah/putih. Pakaian pria Eropa mengilhami model tersendiri bagi pria di Asia tenggara. Celana panjang yang dipadu dengan kemeja tangan pendek dengan ikat pinggang menjadi populer untuk udara panas Asia. Tetapi jika mereka berkunjung ke negara Eropa atau Jepang, maka mereka akan bergaya konservatif.

Pakaian wanita lebih rumit dari pria. Wanita karir Amerika cenderung memakai setelah jas-celana (berbau maskulin) yang tentunya dari bahan yang lebih halus daripada rekan prianya. Sedangkan wanita di Jerman dan di Perancis lebih feminis dalam berpakaian. Mereka memakai rok pendek dengan blouse yang beraneka ragam. Anehnya kurang banyak wanita yang menduduki 
posisi manager dikedua negara tersebut. Bila mereka ingin sampai pada posisi puncak, nampaknya mereka harus menyesuaikan diri dengan pakaian bergaya maskulin dari Amerika.

Di jepang wanita bekerja sebagai pekerja yang menyediakan minum dan menyambut tamu. Pakaian mereka umumnya seragam yang disediakan oleh perusahaan berupa setelah dengan blouse, sarung tangan putih dan sebuah topi.

Dalam banyak budaya, pakaian juga memberi petunjuk asal kelompok dan status mereka. Pakaian bisa melindungi seseorang, bisa juga sebaliknya.

Contoh: pemerintah Jepang pernah mengeluarkan peraturan bagi wanita Jepang yang mukim di Jerman agar tetap menggunakan setelan biru-tuanya dengan

blouse dan sepatu setelah jam kantor untuk menunjukkan bahwa mereka bekerja dan bukan pendatang illegal/pengangguran yang mencari kerja di Jerman.

Dengan berkembangnya keadaan dimana orang menginginkan kenyamanan dan meningkatnya aktivitas hiburan, nampaknya sikap terhadap pakaian pun sekarang lebih santai. Pakaian seperti celana jeans, sepatu tennis dan kuas hampir ditemui disemua belahan dunia saat ini. Bahkan para dokter medis pergi interview ke Rumah Sakit dengan Jeans.

Generasi berpakaian santai ini akan mengalami kesulitan dan mungkin menjadi masalah yang serius bila harus berjumpa dan berbisnis dengan generasi tua yang masih memegang teguh cara berpakaian yang mengikuti norma lama karena mereka menganggap orang muda tidak respek terhadap mereka.

\section{Diam}

Banyak orang menghubungkan komunikasi dengan melakukan sesuatu secara verbal, nonverbal atau juga keduanya. Komunikasi artinya melakukan suatu aktivitas, yaitu mengirimkan pesan dan menerima pesan, mengolah pesan dan memberi respon. Sepintas sikap diam menunjukkan tidak ada sesuatu yang 
dilakukan, padahal 'diam' memainkan peran penting dalam komunikasi di hampir semua budaya. Interpretasi dan pentingnya 'diam' mungkin berbeda antara satu negara dengan lainnya, tetapi semua budaya mengakui dalam 'diam', sesuatu telah terjadi. Perbedaan menggunakan 'diam' mungkin dapat dilihat dari budaya Low Context dan High Context.

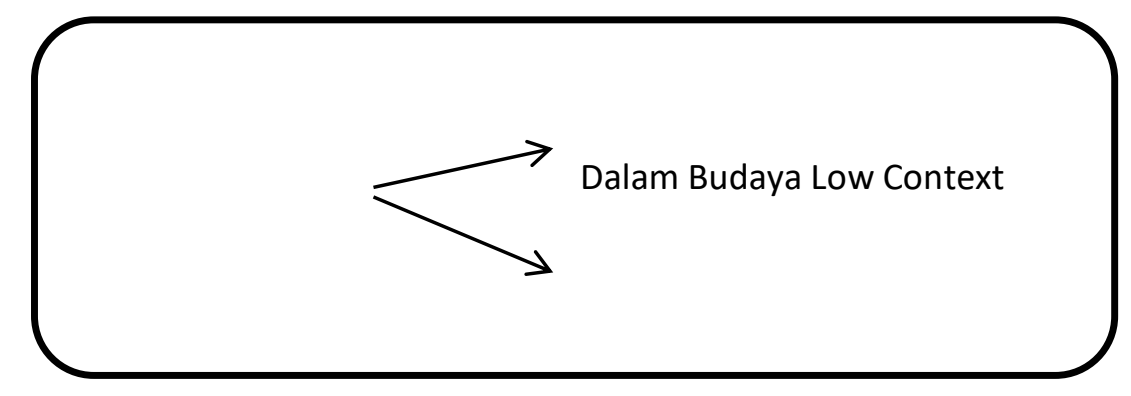

\section{Diam dalam Budaya Low Context}

Dalam budaya Low Context, dimana ide-ide dituangkan dalam kata-kata 'diam' diartikan sebagai tidak adanya suatu komunikasi, tetapi tetap mempunyai arti. Mislanya ketika seseorang berdiam diri dan tidak menjawab setelah pertanyaan dilontarkan padanya, 'diam' itu sudah merupakan jawaban. Ungkapan dalam bahasa Inggris 'Diam itu memekakkan telinga' sudah cukup memberi makna kepada kita arti dari kalimat tersebut. Jika seseorang diam di tengah percakapan, pastilah ada pertanyaan “Ada apa?." Jadi dapat dikatakan bahwa diam itu mengkomunikasikan sebuah pesan. Bisa saja di pendengar tidak mendengar pesan tersebut, marah, malu atau sedang berpikir. Umumnya budaya Low Context mengartikan 'diam’ sebagai gangguan pada komunikasi.

Pepatah Jerman mengatakan 'Bicara adalah perak dan diam adalah emas', nampaknya tidak sesuai dengan batasan 'diam' pada budaya Low Context diatas. Orang-orang dari Low Context akan lebih memilih berbicara daripada diam. 'diam' amat ambigius/mempunyai banyak arti. Oleh sebab itu perlu diartikan dan mengartikan diam ternyata lebih sulit daripada mengartikan kata-kata. Dengan alasan ini orang-orang dari Low Context merasa tidak nyaman dengan 'diam'. 
Mereka merasa bertanggung jawab atas kelangsungan suatu pembicaraan, bahkan kepada orang asing sekali pun. Penumpang di dalam kereta api, contohnya akan bercakap-cakap sepanjang perjalanan.

\section{Diam dalam Budaya High Context}

Dalam budaya High Context, mereka mempunyai pandangan yang berbeda terhadap sikap 'diam'. Contoh yang paling nyata di Asia adalah Jepang. Jepang menganggap 'diam' sebagai bagian dari percakapan. Melalui diam seseorang daoat menemukan kebenaran dalam dirinya. Meditasi dan merenung dilakukan dalam diam. Agama Budha mengajarkan dalam kata-kata terdapat kepalsuan, sehingga orang kepang menganggap dalam kata-kata terdapat kontaminasi makna. Membaca jiwa seseorang adalah suatu komunikasi tanpa kata.

Sikap terhadap diam ini bisa menimbulkan masalah yang serius dalam proses negoisasi bisnis antara orang Amerika dan orang Jepang. Diskusi dalam negoisasi orang Jepang dilakukan dalam kelompok dan dilakukan dengan banyak diam, ekspresi wajah, serta gerak tubuh para anggotanya.

Diam bukanlah sesuatu yang kosong. Dan pembicara Jepang terbiasa dengan banyak diam dalam percakapan dan cenderung tidak terburu-buru dalam mengisi diam/kekosongan dalam percakapan.

\section{KESIMPULAN}

Tulisan ini membahas aspek utama dari simbol nonverbal dalam berbagai budaya. Dalam semua budaya apa-apa yang dikatakan seseorang tanpa kata atau 
ditambahkan pada kata, umumnya berupa simbol-simbol nonverbal. Simbol ini menegaskan kata-kata yang diucapkan, walaupun mereka bisa juga berlawanan dengan kata yang diucapkan.

Dari pembahasan diatas, maka dapat disimpulkan:

* Hampir 93\% diantara pesan verbal/lisan disampaikan secara non-verbal dan elemen-elemen non-verbal umumnya lebih mengena dari pada katakata verbal.

* Makna dan interpretasi sesungguhnya dari sebuah pesan tergantung dari banyak faktor dan karena tidak ada aturan baku tertentu maka kita harus selalu melihat konteks situasi.

* Tanda-tanda non-verbal cenderung dipakai untuk memperkaya dan mensupport bahasa, namun Ia juga mampu mengurangi atau berlawanan dengan pesan verbal.

* Bahasa non-verbal amat beragam dan mengandung banyak makna. Umumnya pembicara menggunakan simbol tersebut secara bersamaan. Hal mana memerlukan perhatian, agar kita dapat men-decode dan dapat menyampaikan pesan dengan lebih efektif.

* Menurut Jallaludin rahmat: bahasa non-verbal/bahasa isyarat termasuk seluruh aspek komunikasi, meliputi lisan dan tulisan.

* Paralinguistik berada diantara komunikasi verbal dan non-verbal karena dianggap hanya melibatkan suara saja, tanpa kata-kata.

* Interpretasi suara tidak menimbulkan suatu kesulitan hubungan dalam komunikasi antar budaya. 
- Simbol-simbol non-verbal adalah refleksi perasaan kita dan respon ketika kita bereaksi, karena kita mengirimkan pesan non-verbal tanpa menyadarinya.

* Pesan non-verbal tidak hanya menemani bahasa verbal, tetapi merupakan bagian yang tidak dapat dipisahkan dari pesan verbal.

* Perubahan perilaku menunjukkan bahwa bahasa non-verbal dapat berubah karena waktu; karenanya belajar komunikasi non-verbal merupakan kegiatan yang harus berlangsung terus menerus.

* Karena lingkungan dari suatu budaya berubah, maka masyarakat harus menetapkan standard komunikasi non-verbalnya dan mencari pengaman untuk melindungi standard tersebut.

* Cara kita berpakaian ternyata berkomunikasi.

* Interpretasi dan pentingnya 'diam' mungkin berbeda antara satu negara dengan lainnya tetapi semua budaya mengakui dalam 'diam' sesuatu telah terjadi.

* Kita tidak bisa memisahkan kebiasaan suatu budaya dari budaya bisnis, karena keduanya berjalan beriringan.

* Bila ingin bekerja sama dengan orang dari budaya lain, maka masingmasing perlu mengatasi perbedaan yang ada.

* Kita bosa saja tidak suka dengan yang dilakukan orang lain, tetapi itu tidak penting. Masalahnya adalah kita harus memahami apa yang dilakukan orang lain dan mengapa mereka melakukannya.

\section{DAFTAR PUSTAKA}

1. Materi makalah kelompok 'The Non-verbal Language in Intercultural Communication.'

2. Deddy Mulyana, Suatu Pengantar Ilmu Komunikasi, PT. Remaja Rosdakarya, Bandung,2003

3. Jallaludin Rakhmat, Psikologi Komunikasi, PT. Remaja Rosdakarya, Bandung, 
